\title{
La sucesión de Enrique IV
}

\author{
M. ${ }^{2}$ ISABEL DEL VAL VALDIVIESO *
}

Quizá resulte superfluo señalar que el problema que se plantea a lo largo del reinado de Enrique IV, en torno a su sucesión, no es sino uno de los episodios más espectaculares de la lucha por el poder que tiene lugar en la Castilla de ese momento. No obstante se hace necesario partir de esa observación a la hora de explicar las causas y el desarrollo de esa lucha, así como el por qué de la aparición del problema sucesorio.

A fines de la Edad Media, en todo el Occidente Europeo las transformaciones que afectan a las diversas monarquias se hacen cada vez más marcadas. Las nuevas teorías políticas y las mejores circunstancias socioeconómicas favorecen la aceleración de los cambios, al tiempo que avivan el fuego de la ambición política, así como los deseos de autonomía de alguno de los poderes del momento. Si lo primero afecta fundamentalmente a la nobleza, el segundo aspecto viene protagonizado por las ciudades.

Como otras entidades políticas, la corona castellana se ve inmersa en esa dinámica de cambios que, al calor de la crisis bajomedieval, ha producido ya diversos conflictos políticos, que durante el reinado anterior culminaron con la ejecución en Valladolid del poderoso don Álvaro de Luna. Tras ese sangriento acontecimiento, las tensiones parecen calmarse, sin embargo no es más que eso, apariencia. En realidad las causas de los enfrentamientos no han desaparecido, de ahí que vuelvan a estallar cuando el nuevo monarca, Enrique IV, de las primeras muestras de debilidad.

\footnotetext{
* Profesora Titular de $\mathrm{H}^{a}{ }^{a}$ Medieval. Universidad de Valladolid.
} 
Siendo príncipe, don Enrique había protagonizado diversos enfrentamientos con su padre, en los cuales aparece como el adalid de una parte de la nobleza, entre la que ya se encuentra Juan Pacheco, que de ser paje de Álvaro de Luna, pasó a servidor del heredero de la Corona. Cuando éste acceda al trono, don Juan va a permanecer a su lado mientras conserve la esperanza de manejar al rey conforme a sus intereses; cuando considere perdida toda posibilidad en ese sentido, se levantará contra él, como veremos enseguida.

La actitud del heredero enfrentado con su padre había hecho concebir serias esperanzas a aquella parte de la nobleza deseosa de suplantar, de hecho, al monarca en el ejercicio del poder supremo. Pero serán esperanzas vanas, no porque Enrique se manifieste como un rey fuerte, sino porque no cede las riendas del gobierno a quien estos nobles desean.

Una vez en el trono, Enrique intentará, utilizando para ello todos los medios a su alcance, gobernar rectamente y hacerse respetar por todos los sectores del reino. Con este fin procura establecer un clima de paz y favorecer a los distintos componentes de la corona castellana, lo que explica su apoyo a la Hermandad y las distintas exenciones que concede a los núcleos de población menos favorecidos ${ }^{1}$. Pero su preocupación se centra muy especialmente en la nobleza, en relación con la cual va a protagonizar desde el primer momento una política de atracción, basada en las donaciones de señoríos y rentas, que en nada favorecerá su prestigio y poder. Al contrario, ante este comportamiento regio, los núcleos urbanos y en general todos aquellos que se sienten perjudicados al ser cedidos a algún señor, contestan las mercedes reales, siendo frecuente encontrar en los Cuadernos de Cortes referencias al disgusto que esto provoca. Pero las protestas no son eficaces ya que la nobleza, o al menos una facción de esta clase, que se siente excluida o no suficientemente bien tratada o recompensada por parte del rey, presiona a éste obligándole a ampliar las mercedes concedidas. De esta forma el monarca $s \in$ ve inmerso en una espiral de donaciones muy poco favorable a su causa, no sólo por la reacción negativa que provoca en aquellos que ven amenazada su autonomía por el progreso del poder nobiliar, sino también porque parte de los nobles ve con recelo una política que juzgan excesivamente magnánima.

\footnotetext{
1 VAL VALDIVIESO, M. I. DEL, "Las medidas repobladoras, un aspecto del reinado de Enrique IV», Cuadernos de Investigación histórica, núm. 7, 1983, págs. 19-33.
} 
Considerando globalmente a la nobleza, puede decirse que su actitud en lo que a las mercedes se refiere, viene explicada por la necesidad de remontar definitivamente la crisis. Al verse inmersos en ésta han reaccionado buscando la forma de salvar primero, y afianzar después, sus rentas y su poder. Respecto a las primeras parece existir unanimidad a la hora de considerar al monarca como un dispensador y redistribuidor de las mismas; de ahí que exijan mercedes de todo tipo, que siempre vienen a favorecer la situación económica del beneficiario. Pero no se trata sólo de rentas en sentido estricto: la participación en el poder es cada vez más importante, y si en el primer aspecto casi todos parecen estar de acuerdo, en este segundo las posturas de unos y otros representantes de la clase nobiliar son divergentes.

Parece evidente, y ya hablé de ello en otra ocasión ${ }^{2}$, que durante el reinado de Enrique IV la nobleza castellana está dividida en dos sectores enfrentados en torno al problema de cómo participar del poder en Castilla. Si una parte de la misma, la más «moderna», representada fundamentalmente por la familia Mendoza, considera necesaria una cierta prudencia, otro grupo, encabezado por el marqués de Villena, Juan Pacheco, está dispuesto a marginar sin muchas contemplaciones al rey. Los primeros intentan conseguir parcelas de poder en las más altas esferas de gobierno, pero salvando la participación del monarca, figura clave que garantizaría el equilibrio y, sobre todo, su acceso a los asuntos relativos a la dirección del reino. Los segundos rompen con todo subterfugio y pretenden, mientras el rey caza o se dedica a cualquiera de sus otras actividades lúdicas favoritas, gobernar sin trabas la corona castellana.

No cabe duda de que para el reino es más aceptable la primera actitud que la segunda, dado el respeto que manifiesta con respecto a la institución y a la propia persona del rey, sin embargo quienes dejan oír su voz en las Cortes no participan activamente en esta discusión: sus intereses y preocupaciones son otros, en especial, en relación a lo que ahora nos ocupa, mantenerse en el realengo. Esto explica que el resto de los castellanos no intervenga en disputas teóricas ni en la lucha por el poder en la corte que enfrenta entre sí a la clase dominante, aunque, como veremos, sí van a vivir, y a utilizar, a su modo, el conflicto sucesorio, en torno al cual dirimen sus diferencias los dos sectores en que se fragmenta la nobleza.

2 VAL VALDIVIESO, M. I. DEL, «Los bandos nobiliarios durante el reinado de Enrique IV", Hispania, 130, (1975), págs. 249-294. 
Junto a esto, para entender en toda su complejidad por qué surge y alcanza tanta virulencia la crisis sucesoria, también hay que tomar en consideración el problema catalán y las diferencias que separan a Juan II de Aragón del monarca castellano.

Enrique IV de Castilla participa en los conflictos internos de la corona aragonesa, concretamente en la guerra de Cataluña, llegando a aceptar el señorío de los condados catalanes frente a Juan II de Aragón ${ }^{3}$. Parece lógico entonces, que a partir de este momento las relaciones entre ambos monarcas sean en general tirantes, y que Juan II aproveche toda circunstancia que se le presente para minar las fuerzas del castellano y hacer pasar sus intereses por encima de los de éste. Esta rivalidad entre los dos monarcas más relevantes de la Península, unida a la ambición política del aragonés, alimentará la crisis sucesoria castellana, sobre todo desde el momento en que éste logre imponer a su hijo Fernando como marido de la princesa Isabel.

En tercer lugar, hay que prestar atención a los poderes urbanos, notablemente afianzados ya en este momento, y que pugnan por defender su autonomia frente a las injerencias de la corona y la expansión del régimen señorial. Los núcleos urbanos castellanos han tenido que aceptar al corregidor, que al final del período que nos ocupa se ha impuesto ya en todas partes. Pero lo que no están dispuestos a aceptar es la intervención de la voluntad regia en el nombramiento de regidores y los oficiales del concejo. En este sentido todos los intentos del monarca serán fallidos: la clase dominante urbana logra mantener bajo su control el nombramiento de los cargos concejiles, es ella la que nombra de hecho, mientras el rey no hace sino confirmar lo que la ciudad le presenta. Cuando las cosas no suceden de este modo, la resistencia a la intromisión real es tenaz y generalmente logra imponerse.

Junto a este deseo de afirmar y defender su autonomía en lo referente al nombramiento de cargos concejiles, los núcleos urbanos, en general, defienden también con ahínco su pertenencia al realengo, mostrando una clara voluntad contraria a ser cedidos a la autoridad nobiliar. Sin duda el poder real, más lejano y laxo que el señorial, debía ser más soportable. Esto explica las dificultades de Enrique IV con los concejos: la política de mercedes del rey es lesiva para los intereses urbanos, causa por la cual no es aceptada por aquellos que se ven "expulsados" del dominio de la corona. Los ejemplos que podrían mencionarse son

${ }^{3}$ Sobrequés I Callico, J., Enric IV de Castella, senyor del principat de Catalunya. Barcelona 1989. 
abundantes ${ }^{4}$, valga de momento con la actitud de los vecinos de San Felices de los Gallegos, que recibieron a pedradas a su nuevo señor, Gracián de Sese, cuando éste intentó hacer efectiva la donación que en su favor habia realizado don Enrique ${ }^{5}$.

Así pues, a pesar de su buena intención, la política seguida por Enrique IV desde el comienzo de su reinado no parece la más adecuada para atraerse la voluntad del reino y evitar disturbios. Sin duda su comportamiento responde a un intento de afianzar su posición, ganarse la voluntad nobiliaria, y controlar las diversas esferas de poder existentes en el reino, pero los resultados son muy otros: la división interna, la crisis sucesoria, la guerra civil.

\section{EL PLANTEAMIENTO DEL PROBLEMA}

La primera etapa del reinado de Enrique IV viene marcada por la influencia poderosísima que Juan Pacheco ejerce en la práctica del poder, hasta el punto de poderse decir que es éste más que el rey quien gobierna en Castilla. Pero su ambición política, y la competencia que otros nobles afectos al monarca (en especial Beltrán de la Cueva) representan para él, lleva al marqués de Villena a enfrentarse con su señor.

Las diferencias estallan en torno al tema de la custodia de los infantes, los dos hermanastros del rey, que viven en la corte regia desde 1461. Sin duda la guardia de tan altos personajes representaba una importante baza para quien la ejerciera, causa por la cual los ánimos se enconan. Pero no hay que olvidar que lo que está realmente detrás del pulso que unos y otros echan en torno a este asunto, no es más que la defensa de unas prerrogativas que algunos miembros de la clase nobiliar, quizá excesivamente susceptibles, sienten lesionadas 0 amenazadas. En efecto, Pacheco ha comenzado a mostrar su disgusto con alguna de las actuaciones del rey, y ese disgusto le va a llevar a utilizar el asunto de los infantes para romper su relación con él.

${ }^{4}$ A este respecto puede verse, a título de ejemplo, VAL VAldivieso, M. I. DEL, «Resistencia al dominio señorial durante los últimos años del reinado de Enrique IV", Hispania, 126 (1974), págs. 53-104.

${ }^{5}$ Capitulo VIII de la crónica de los Reyes Católicos de Hernando del Pulgar, editada por C. Rosell, en el tomo Ill de Crónicas de los Reyes de Castilla. Madrid, Biblioteca de Autores Españoles, 1953, pág. 237. 
El 16 de mayo de 1464, los protagonistas de la primera fase del conflicto. Alfonso Carrillo --arzobispo de Toledo-, el maestre de Calatrava don Pedro Girón, y su hermano Juan Pacheco suscriben un documento exigiendo la guarda de los infantes Isabel y Alfonso. Tras un forcejeo con el rey, y una vez establecido el acuerdo matrimonial de Alfonso con la princesa Juana, los hermanastros del rey son entregados a la liga nobiliaria. El problema sucesorio arraiga con las condiciones de esta entrega: no sólo Alfonso queda prometido en matrimonio a Juana, sino que en la sucesión se relega a ésta en beneficio del infante, pues el rey se compromete a nombrar heredero a su hermano ${ }^{6}$. Antes de seguir adelante se hace necesario aclarar dos cosas.

Primero, la línea sucesoria que ha sido establecida por Juan II. EI predecesor de don Enrique deja como heredero indiscutible a su hijo primogénito, y a falta de éste da preferencia al varón sobre la mujer, puesto que, aunque Isabel es mayor que su hermano Alfonso, sería éste el llamado a suceder a Enrique en caso de que muriera sin dejar heredero/a al trono. Isabel queda en tercer lugar con muy escasas posibilidades de alcanzar la corona ya que, según el testamento de su padre, sólo si sus dos hermanos mueren sin descendencia legítima tendria que ser llamada a la sucesión.

La segunda cuestión se refiere a la hija del rey, doña Juana. Sabido es que la primera unión de Enrique IV, realizada con Blanca de Navarra, es disuelta dado que el marido no es capaz de consumar el matrimonio. Tras este fracaso, un tanto vergonzante, el heredero castellano se casa con una mujer de la casa real portuguesa, Juana. El matrimonio tarda en dar fruto. Por fin, después de siete años nace una niña, que es alegremente celebrada como hija del rey y futura heredera del trono ${ }^{7}$. En el momento de su nacimiento, en 1462, nadie parece poner en duda la identidad del padre de la neófita, pero pocos años después las cosas cambian y comienza a discutirse que el rey sea su padre. Llegados a este punto no creo necesario insistir en que el rumor popular atribuye la paternidad a don Beltrán de la Cueva, de donde derivará el apodo dado posteriormente a la niña: «La Beltraneja».

Si en el momento de su nacimiento nadie duda del origen de Juana, en 1464 los rumores sobre la ilegitimidad son insistentes. Así están las cosas respecto a la niña cuando el rey se compromete a entregar a sus

${ }^{6}$ Memorias de Enrique IV de Castilla, t. II, "Colección Diplomática». Madrid, Real Academia de la Historia, 1835-1913, doc. núm. 101, págs. 337-340.

Véase apéndice documental 1. 
hermanastros a la liga nobiliaria, y acepta relegar de la sucesión a su hija en beneficio de Alfonso. Esta decisión se explica seguramente en función de su permanente deseo de concordia - a lo largo de todo su reinado va a dar sobradas pruebas de su voluntad pacifista-, y quizá también porque tanto él como los que en ese momento le aconsejan y apoyan consideran que al ser su descendiente una mujer podría ser postergada, sin provocar graves problemas, en favor de su tío-marido, máxime cuando con este sacrificio se creía garantizar la paz del reino.

Pero nada más lejos de la realidad. Si en septiembre de 1464 el rey reconoce a Alfonso como su heredero, siempre y cuando se case con su hija Juana, pocos meses después, en 1465, se inician las hostilidades entre don Enrique y la liga nobiliar rebelde encabezada por los hermanos Girón y Pacheco y por el arzobispo Carrillo, representantes, en líneas generales, de la postura política más conservadora y virulentamente defensora de una participación en el poder regio que suponía la marginación en la práctica del papel del monarca.

El inicio de los acontecimientos tiene lugar en Ávila, en un acto de gran teatralidad y contenido simbólico ${ }^{8}$. Los rebeldes coronan rey a don Alfonso, considerando depuesto a Enrique IV, al que acusan, entre otras cosas, y como ya lo han dicho crudamente en la "Sentencia de Medina del Campo" de enero de $1465^{\circ}$, de no cumplir sus obligaciones reales, es decir, de no gobernar el reino como debía.

Unos días antes de la fiesta del Corpus, que ese año se celebró el 13, los rebeldes organizan la espectacular deposición de Enrique IV el día 5 de junio de 1465. El montaje, además de vistoso, fue de una gran eficacia política desde el punto de vista propagandístico: sobre un tablado preparado al efecto, se procedió a despojar de los atributos reales a un muñeco que representaba al rey, y que finalmente fue empujado del trono, cayendo al suelo. A continuación esos atributos de poder le son entregados a Alfonso, que es proclamado rey: sus partidarios le llaman Alfonso XII.

Los responsables de esta representación sabian perfectamente 10 que hacían. La utilización de un muñeco revestido con los atributos de la realeza representaba claramente al rey, para la opinión popular "era" el rey sin ningún género de dudas. Éste era un mensaje que los castellanos

${ }^{3}$ Este acto celebrado en Ávila ha sido brillantemente estudiado por MACKAY, A., «Ritual and propaganda in fifteenth-century Castille", Past and Present, 107, 1985, págs. 4-43.

${ }_{9}$ Documento publicado por SiTGEs, J. B., Enrique IV y la excelente señora llamada vulgarmente doña Juana la Beltraneja. Madrid 1912. 
de entonces podían captar fácilmente. Pero en la «Farsa de Ávila» hay todavía otros elementos (muy inteligentemente puestos de manifiesto por el Profesor Mackay) que explican su eficacia política y su éxito popular inmediato: a la efigie del rey se le fueron quitando uno por uno los atributos de la realeza, y éstos fueron posteriormente entregados a Alfonso, quien sucesivamente va recibiendo la corona, la espada, el cetro y el trono, para ser finalmente aclamado como rey. Este ceremonial es similar al que se sigue en las honras fúnebres del monarca fallecido y la posterior proclamación de su sucesor: precisamente en Ávila, cuando el 18 de diciembre de 1474 se celebran las exequias por Enrique IV encontramos un acto similar. También en esta ocasión se levanta un tablado (no al aire libre sino en el interior de la catedral) y allí se llora al monarca desaparecido, representado por un negro catafalco. Inmediatamente después, en la misma catedral por cierto, la comitiva fúnebre cambia sus vestimentas de luto por otras de fiesta, y subiéndose al mismo tablado del que se ha retirado al "rey" desaparecido, es decir, el catafalco que lo representaba, corean los gritos de júbilo del alférez: “iCastilla, Castilla por la muy alta e esclarecida señora nuestra señora la reina doña Isabel!». De esta forma, sin traumas, sustituyen a un rey por su sucesor.

Algo semejante se hizo en Ávila ese 5 de junio de 1465: lo que querian significar quienes protagonizaron la escenificación era que el rey "había muerto" para el ejercicio del gobierno, por lo que era necesario proceder a la proclamación de su sucesor.

Pero es que hay aún más. Un tercer aspecto que según A. Mackay contribuye a explicar tanto el ceremonial adoptado por los sublevados, como su aceptación por parte de numerosos habitantes del reino. Se trata de la integración de la "Farsa» en los festejos propios del Corpus. En efecto, con motivo de esta fiesta era frecuente en todo el reino la representación de obras de carácter teatral, para lo cual se levantaban escenarios por todas partes. Por tanto, la deposición de Enrique IV, en un tablado instalado en la plaza pública sobre el que diversos personajes representaban un grave drama político, precisamente muy pocos días antes de la celebración de esa fiesta solemne, puede ser interpretado como un gesto «didáctico" de los sublevados (no hay que olvidar que Carrillo tiene un papel protagonista en todo esto). Con ello pretendían hacer comprender al reino su postura, explicar el por qué de la misma, y proclamar, con la máxima brillantez posible, al que decian, era el único y legítimo sucesor del trono: Alfonso "XII».

Es decir, los sublevados sabian muy bien lo que se hacían, lo que querían y cómo conseguirlo. Parece que su objetivo era dominar el gobierno del reino: considerando que Enrique IV no les permitía actuar con- 
forme a sus deseos y aspiraciones, deciden sustituirle por otro monarca - no se olvide que se trata de un menor de edad- más favorable a sus pretensiones, más manejable en definitiva (en este sentido permítaseme adelantar que la ruptura posterior de Carrillo con Isabel se debe en parte a que ésta y sus consejeros más directos no le dejan actuar con la libertad que él desearía).

Obviamente, si Enrique IV había cedido en lo referente a la sucesión por mantener la paz, lo que no está dispuesto a hacer es renunciar al trono por esa ni por otra razón. Y sus partidarios del momento, el otro sector de la levantisca nobleza, el que, andando el tiempo, acabará uniéndose al bando isabelino, tampoco aceptaría una actitud semejante. La consecuencia es, pues, fácil de prever: la guerra civil.

El reino se divide entre ambos contendientes. Enrique busca la ayuda de Portugal, mientras los sublevados procuran por todos los medios a su alcance, y en especial a través de mercedes, atraer hacia su causa al mayor número posible de seguidores. Hasta 1468 en que muere don Alfonso son escasas las confrontaciones armadas de ambos ejércitos. Entre ellas destacan, sin duda, el cerco de Simancas por las tropas reales y la batalla de Olmedo de 1467, en la que el ejército alfonsino fue derrotado. El episodic es narrado con detalle por los cronistas, entre ellos Galíndez de Carvajal ${ }^{10}$. Pero aunque habitualmente no se produzcan enfrentamientos bélicos, el conflicto se extiende por todo el territorio de la corona castellana, siendo aprovechado, lo mismo que lo será en el período siguiente, para solventar querellas particulares y luchas por el poder en el ámbito local. Así pues, el reino se encuentra dividido cuando en 1468 muere el infante.

Hasta que en los últimos meses de 1467 los sublevados intentan tomar la fortaleza de Segovia, defendida hábilmente por la reina Juana, Isabel permanece en la corte real ${ }^{1 i}$. Durante ese tiempo la infanta había sido utilizada por su hermano el rey como instrumento de negociación.

10 ToRRES Fontes, J., Estudio sobre la crónica de Enrique IV del doctor Galíndez de Carvajal. Murcia 1946, cap. 89, págs. 299-303. Sobre el cerco de Simancas puede verse el cap. LXXX de la crónica de Enrique IV de Enríquez del Castillo, editada por C. Rosel, ob. cit. Al narrar estos hechos el cronista señala que «los gastos eran excesivos en las pagas del sueldo" de quienes estaban con don Enrique; durante el cerco se intenta en vano la negociación entre ambos bandos, de manera que el cronista llama la atención sobre el doble fracaso que la acción supuso, ya que no se logró ni la victoria por vía de las armas, ni la paz a través de las conversaciones habidas.

11 Sobre la primera etapa de la vida de Isabel véase. SuÁrez FernÁndez L., Los Reyes Católicos. La conquista del trono. Madrid 1989, págs. 11-12. 
Con motivo del conflicto aragonés Isabel se ve envuelta en tratos matrimoniales con Fernando y con el príncipe de Viana; ya durante la sublevación nobiliar se planeará su unión con Alfonso $\mathrm{V}$ de Portugal y posteriormente, con el objeto de firmar la paz con los rebeldes, con el hermano de Juan Pacheco, el maestre de Calatrava Pedro Girón. Aunque no parece que a Isabel le gustara el proyecto, este cuarto acuerdo estuvo a punto de realizarse. Fue la muerte del pretendiente lo que impidió que en esta ocasión la infanta liegara al altar ${ }^{12}$.

Este último episodio debió enturbiar las relaciones entre los hermanos, de manera que Isabel parece especialmente contenta cuando se encuentra de nuevo con Alfonso, como lo demuestra su participación activa en la fiesta del décimocuarto cumpleaños de éste, celebrada en diciembre de $1467^{13}$.

Siete meses después Isabel salta al primer plano de la política castellana: Alfonso muere en Cardeñosa el 5 de julio de 1468, y casi inmediatamente después empieza a ser vista como su posible sucesora. Sin embargo la infanta, que ha vivido muy de cerca todos los acontecimientos anteriores, y que demuestra tener una gran inteligencia política, no va a permitir que la manejen tan fácilmente, y sobre todo va a posibilitar la firma de la paz haciéndose reconocer oficialmente heredera de Enrique IV, actitud que a la larga le favorecerá notablemente.

\section{DE GUISANDO A VALDELOZOYA}

Con la muerte de Aifonso el bando rebelde ha perdido la única pieza que podía justificar su conducta: un miembro de la familia real dispuesto a secundar sus pretensiones, y esto además cuando las circunstancias políticas castellanas no eran muy favorables a su causa. Si querían evitar la derrota era necesario encontrar un sustituto al fallecido infante, y esto les lleva hasta su hermana. Con la infanta a su lado, los rebeldes pac-

12 Val Valdivieso, M. I. DEL, «Relaciones de don Pedro Girón, maestre de Calatrava, con el rey don Enrique IV", VII Centenario del infante don Fernando de la Cerda (12751975). Madrid 1976, págs. 159-170.

13 Morales Muñiz, M. D., Alfonso de Ávila, rey de Castilla. Ávila 1988, págs. 233-237. 
tarán con el monarca, y de esta forma la futura reina Católica se convertirá en princesa heredera de Castilla ${ }^{14}$.

A raíz del fallecimiento de su hermano, en el mes de julio, Isabel se titula ya princesa - como heredera de Alfonso- pero no acepta ser coronada, e insiste en pactar con Enrique su reconocimiento como legítima heredera del trono. En este punto se produce una cesura en el grupo rebelde, cuyo conocimiento es fundamental para comprender el posterior matrimonio de Isabel y todos los acontecimientos que le siguen: cada uno de los dos cabecillas del bando rebelde adopta una postura distinta y enfrentada. El maestre de Santiago, que, dada la situación política, ve posible volver junto al rey y recobrar su posición preeminente, de la que espera obtener notables ventajas, es partidario de pactar con Enrique el reconocimiento de Isabel como heredera. El arzobispado de Toledo, amigo y aliado del rey aragonés más coherente con el principio motor del conflicto, pretende mantener el enfrentamiento armado, coronando directamente a Isabel reina de Castilla, lo mismo que antes habían coronado a su hermano.

No cabe duda de que desde el primer momento la infanta se muestra totalmente dedicada a conseguir la corona de Castilla; para alcanzar ese objetivo se le presentan dos opciones, y entre ellas considera más favorable pactar con el rey, en la convicción de que al precio de alargar el plazo al cabo del cual podrá alcanzar de trono, queda asegurada, a su juicio, la llegada a la meta final. El tiempo le dará la razón, aunque ese éxito supuso una nueva guerra civil, más virulenta que la protagonizada por su hermano Alfonso. Por el momento, conforme a esta convicción, Isabel se une a Pacheco, y sin romper con Carrillo, con quien firma un compromiso de amistad, pacta con el rey.

En septiembre de 1468, en los Toros de Guisando, Isabel es reconocida oficialmente heredera de Castilla. Para ello se aparta de la herencia a la discutida hija del rey, en función de la supuesta ilegitimidad del matrimonio de sus padres. Se dice entonces que Enrique IV y Juana de Portugal, unidos por vínculos de consanguinidad, no solicitaron la necesaria bula de dispensa, causa por la cual canónicamente la unión no es legítima y, por tanto, tampoco lo es su descendencia. Basándose en esa afirmación Enrique ordena que Isabel sea jurada princesa, al tiempo que, para atender sus necesidades, le hace entrega de Medina del Campo,

14 Los acontecimientos a los que me voy a referir a continuación pueden seguirse por extenso en Val Valdivieso, M. I. DEL, Isabel la Católica princesa (1468-1474). Valladolid 1974; cuando no se indique otra referencia los datos aportados proceden de esta obra. 
Ávila, Alcaraz, Escalona, Molina y, por supuesto, el principado de Asturias. Entre otras cosas, en ese pacto ambas partes aceptan que el enlace matrimonial de la nueva princesa será establecido de común acuerdo entre ella misma, algunos grandes nobles y el rey.

Aunque el acto de Guisando no reviste la solemnidad ni es tan simbólico como la famosa «Farsa de Ávila» también pueden encontrarse en el mismo elementos claramente «didácticos», que explican la trascendencia del mismo. En este sentido destacan especialmente diversos gestos del arzobispo Carrillo: lleva las riendas de Isabel, en clara muestra de servicio hacia ella, y se niega a besar la mano de Enrique, demostrando así no estar dispuesto a someterse al rey mientras no se cumplan los planes previstos, es decir el reconocimiento de Isabel como heredera legítima ${ }^{15}$. (Recuérdese que Carrillo no es partidario de este pacto, y que acepta participar en el mismo únicamente porque las circunstancias se lo imponen).

En Guisando, pues, Isabel logra ser reconocida heredera legítima de la corona castellana y de momento todo parece indicar que el conflicto ha terminado. Sin embargo las cosas no van a suceder como se acordó en esa ocasión, y ese pacto tampoco va a sellar el final de las hostilidades.

La lucha por el poder está lejos de haber sido zanjada con los últimos acontecimientos. Lo único que se va a producir es un cambio en las alianzas, fruto de la división surgida en el bando rebelde y de la puerta abierta que Pacheco encuentra en la corte real, a la que vuelve a integrarse con la clara intención de satisfacer sus deseos de poder.

En efecto, muy poco tiempo después del pacto de Guisando podemos ver ya a Pacheco junto al rey, mientras Carrillo no solo sigue al lado de la nueva princesa, sino que, fiel a sus amigos aragoneses y a su enemistad con el rey, procura apartar a Isabel de su hermano. Lo conseguirá sin grandes dificultades.

Si en septiembre de 1468 se había impuesto la opinión de Juan Pacheco, defensor de la oportunidad política del pacto, poco después el triunfador será Carrillo, que pronto se gana la voluntad de la princesa y se convierte en su principal consejero.

${ }^{15}$ La escena viene narrada con suficiente claridad en la «Crónica de Enrique IV» de Galíndez de Carvajal, editada por Torres Fontes, Estudio..., cap. 102, pags. 334-337. 
Tras firmar la paz con su hermano, Isabel acude con él a Ocaña. Pero aquí se siente excesivamente controlada y presionada por el rey y sus hombres. Esta circunstancia, junto a la insistencia del arzobispo que procura convencerla de su forma de ver las cosas, hace que la princesa tome la decisión de huir de la corte. Se refugia en Madrigal de las Altas Torres, al amparo del arzobispo, quien pronto hará triunfar a su pretendiente a la mano de la princesa, Fernando de Aragón.

Una vez convertida en heredera le rondan cuatro pretendientes: un hermano del rey Eduardo IV de Inglaterra, que será el futuro Ricardo II; el rey de Portugal Alfonso $\mathrm{V}$, de quien no hay que olvidar que es hermano de la reina de Castilla, y por lo tanto tío de la discutida hija del rey; el duque de Berri y Guyena, hermano y posible heredero en ese momento del rey de Francia; y Fernando de Aragón.

Enrique IV duda entre el pretendiente francés y el portugués, ya que ambas alianzas, por distintas razones, favorecerian sus intereses políticos. Pero Isabel, dejándose guiar, no por su hermano, sino por el arzobispo, va a rechazar a ambos. Carrillo y los suyos, dada su amistad con el rey aragonés Juan II, explicada en parte por la enemistad tradicional que separa a éste del rey castellano, optan desde el primer momento por el príncipe Fernando.

Y esta opción es la que se impone. Isabel, cuando todavía está en Ocaña, es decir, antes de abandonar la corte real, resiste la presión del rey y se niega a dar su consentimiento para establecer su enlace matrimonial con el rey portugués; y esto a pesar de que incluso es amenazada con ser encerrada en prisión, en el alcázar de Madrid, si no acepta a ese candidato. Ya en Madrigal, rechaza también, suavemente pero con firmeza, al pretendiente francés, y convencida por Carrillo, y animada por los esperanzadores informes que le traen sus embajadores, optan por el pretendiente aragonés.

Para cuando la princesa se decide, Fernando y su padre habían firmado ya, en Cervera ( 7 de enero/5 de marzo de 1469), las capitulaciones matrimoniales. La existencia de este compromiso y lo anticipado de su realización, se explica por la exigencia que en este sentido habían impuesto a los aragoneses el arzobispo de Toledo y los suyos. Éstos, a pesar de ser fieles partidarios de esa opción, no pueden evitar una cierta desconfianza respecto a la posible conducta futura del novio, temen que les reste poder, de ahí que intenten poner todos los obstáculos posibles para evitar que eso ocurra. Por esta razón el príncipe se compromete en las capitulaciones, entre otras cosas, a guardar los fueros, usos y costumbres castellanos, y a fijar su residencia en Castilla, junto a su mujer; 
jura también no actuar en este reino sin el consentimiento de Isabel, así como no entregar ninguna parcela de poder a extranjeros, es decir, a los aragoneses que pudieran venir a su lado. En definitiva, ante la desconfianza castellana de cara a la futura conducta del príncipe-rey consorte (Juan II ha cedido a su hijo y heredero el reino de Sicilia), Fernando tiene que aceptar su sometimiento a la voluntad política de la nobleza de Castilla, es decir, tiene que renunciar a la posibilidad de hacerse dueño en algún momento de la situación en este reino. Además se obliga a entregar a su futura esposa, en concepto de arras, diversos lugares de la corona aragonesa, entre ellos Tarrasa, Sabadell, Elche y Crevillente, así como 100.000 florines de oro. Pero todos estos compromisos no adquieren pleno sentido hasta que la heredera castellana toma la decisión definitiva.

Una vez tomada esa importante decisión, se hacía preciso llevarla a la práctica. Para esto era necesario salvar dos difíciles obstáculos: conseguir una dispensa pontificia y lograr que Fernando pudiera reunirse con la novia en Castilla.

Entre los futuros cónyuges existe un parentesco en tercer grado, por lo que, según el derecho canónico, necesitan dispensa pontificia para poder contraer matrimonio. Era preciso por tanto recurrir al papa, pero éste, inclinado hacia la causa de Enrique y contrario a las aspiraciones aragonesas -entre otras cosas porque su política mediterránea así se lo imponía- niega sistemáticamente la necesaria dispensa. La diplomacia aragonesa y la isabelina chocan una y otra vez con la burocracia papal. Pero el bando de la princesa no se arredra, consigue ganar para su causa al legado pontificio, Antonio Veneris, y se hace así con una bula falsa, de Pio ll, en la que se autoriza al príncipe de Aragón a contraer matrimonio con una mujer con la que estuviera emparentado en tercer grado, exactamente el grado de consanguinidad que tenía Isabel con respecto al novio. Con esta bula se casan los príncipes.

El asunto es lo suficientemente oscuro como para que posteriormente Isabel y Fernando, para regularizar su situación, tengan que solicitar a Sixto IV la dispensa con la que no contaron en el momento de su boda. Ante los hechos consumados, y dado que era más afecto a la princesa, el nuevo papa otorga por fin la necesaria dispensa.

El segundo obstáculo se salva también. Fernando entra en Castilla disfrazado, y consigue llegar hasta Dueñas, villa de su abuelo materno el Almirante, y lugar en el que fija su residencia hasta el momento de la celebración del matrimonio. Éste tiene lugar en Valladolid, donde la prin- 
cesa ha encontrado refugio, alojándose en las casas de Juan Vivero. Es aquí, precisamente, donde tiene lugar la ceremonia.

La boda se celebró el 19 de octubre. La víspera por la tarde Fernando llegó a Valladolid, acompañado por 30 caballeros y una nutrida escolta. Fue recibido en medio de grandes muestras de alegría por Carrillo, el Almirante de Castilla, don Fadrique Enríquez, y numerosos vallisoletanos. Al anochecer se trasladó a la residencia de su prometida, donde tuvieron lugar los esponsales con toda solemnidad. El arzobispo dio lectura a la falsa bula de dispensa, tras lo cual se leyeron las capitulaciones matrimoniales suscritas por el novio y ratificadas por su padre, Juan II de Aragón. Por último, Carrillo celebró el desposorio.

Acabado el acto, el príncipe se retiró a la posada del arzobispo, lugar en el que se había fijado su alojamiento en tanto no concluyeran todos los actos del enlace matrimonial.

A la mañana siguiente el novio regresó a la casa de Isabel para la celebración de la boda propiamente dicha. Actuó de madrina la mujer de Juan Vivero, y de padrino el abuelo del príncipe, don Fadrique Enríquez. La misa nupcial fue oficiada por don Pedro López de Alcántara, capellán de san Yuste.

Esa misma noche se consumó la unión de los contrayentes, e inmediatamente despues fue mostrada a los testigos, que según la costumbre castellana esperaban en una sala contigua a la cámara nupcial, la "sábana de la princesa". Vista ésta tocaron las trompetas y dieron comienzo grandes fiestas, que se prolongaron por espacio de siete días. Al cabo de ese tiempo el arzobispo Carrillo ofició una misa solemne en la colegiata vallisoletana, bendiciendo en ella a la nueva pareja.

No cabe duda de que tanto Isabel como sus partidarios eran conscientes de la gravedad de la decisión tomada. Primero la huida de la corte, y por tanto del control del rey. Y por si esto no fuera suficiente la abierta oposición al monarca con una acción que éste considera como lo que en parte es: un reto.

La paciencia de Enrique está colmada, por lo que sin más cautelas rompe abiertamente con Isabel: declara nulo el pacto de Guisando en tanto que una de las partes, precisamente la que a su juicio ha sido la verdadera beneficiada, ha roto el compromiso; hecho esto proclama a Juana como su legítima hija y la hace jurar heredera del trono. Enrique mantendrá esta posición hasta el final de sus días ${ }^{16}$.

\footnotetext{
${ }^{16}$ Sobre la actitud política de Enrique IV a lo largo de su reinado véase PHILLIPS, W.
} 
El acto tuvo lugar en Valdelozoya, en octubre de 1470 , y en el mismo participa activamente, junto al rey, el marqués de Villena. En desacuerdo con la actuación de Isabel y con el papel predominante que a su lado juega el arzobispo de Toledo, Pacheco, el conde de Plasencia y el arzobispo de Sevilla, planean y preparan el acuerdo matrimonial de Juana con el hermano de Luis XI de Francia, el duque de Berri y Guyena, en un intento de fortalecer su postura y poner en mayores dificultades al adversario (adviértase el enfrentamiento existente entre Luis XI de Francia y Juan II de Aragón). El rey aprueba el plan y decide hacer público el compromiso en un acto solemne en el que Juana será jurada de nuevo heredera del trono castellano.

La reina y su hija, que estaban en poder de los Mendoza, son conducidas por éstos al valle del Lozoya. En el lugar de Santiago, entre Buitrago y Lozoya, se encuentran con la engalanada y solemne comitiva real. Tras los gestos rituales realizados por los Mendoza (cuya postura no ha sido muy clara en ningún momento, pues si bien no se alzan contra Enrique, tampoco aceptan plenamente su actuación política) como signo de acatamiento y reconocimiento del rey, y por los miembros de la comitiva real como manifestación de aceptación de la reina y su hija, tiene lugar la solemne proclamación de ésta como legítima heredera del reino, así como el anuncio de su compromiso matrimonial con el de Guyena. Previamente, por supuesto, el rey declara invalidado el pacto de Guisando y por tanto el reconocimiento de Isabel; y además, para satisfacer las exigencias de los franceses, y sin duda, también, para disipar la desconfianza que al respecto existía en el reino, Enrique y Juana juran solemnemente que la niña es hija de ambos. Por fin Juana fue jurada heredera por los participantes en el acto, y se la desposó, por palabras de presente, con Carlos de Guyena ${ }^{17}$.

Frente a la tesis y actitud real, Isabel sostiene que, dado que se realizó bajo la autoridad apostólica del legado pontificio, el juramento de Guisando no puede ser absuelto por el monarca, y que por lo tanto ninguna autoridad laica puede revocarlo. Aferrándose a esa interpretación y a que Juana no es hija de legítimo matrimonio, se reafirma como heredera, e inicia una política de captación de partidarios entre las ciudades y los nobles del reino. Realiza incluso continuados intentos de recuperar

D., Jr., Enrique IV and the crisis of fifteenth-century Castile (1425-1480). Massachusetts, Cambridge 1978.

17 Inmediatamente el rey comunica los acontecimientos y ordena que reconozcan por heredera a Juana (Memorias, doc. núm. 179, págs. 619-621). 
su amistad con el rey, con quien llega a entrevistarse en Segovia. Pero todo es en vano, Enrique no volverá a aceptarla como heredera.

Isabel y sus partidarios se declararán, a partir de este momento, firmemente convencidos de que el asunto del matrimonio no tiene nada que ver con la legitimidad de su condición de princesa, y de que Juana no puede ser aceptada como tal dado el irregular matrimonio de sus padres (en general ahora se procura obviar el escabroso asunto de la paternidad). Basándose en este argumento legal, y en un principio político materializado en la defensa de los intereses del reino y de los castellanos, mediante el amparo dado a los nobles en la protección de sus derechos e intereses y la proclamación (que no se corresponde realmente con su actuación) ${ }^{18}$ de la defensa del realengo frente a las aspiraciones nobiliarias (condenando por tanto la abusiva concesión de mercedes realizada por Enrique), los príncipes y sus seguidores buscan ampliar el número de sus partidarios, al tiempo que intentan ganarse incluso la voluntad real.

En esa captación de partidarios y conquista de nuevas lealtades el recurso de las armas es escasamente utilizado, pero sí se emplea en alguna ocasión. El caso de la conquista de Tordesillas, por ejemplo, es claro en este sentido, pero no deja de ser realmente una excepción ${ }^{19}$. La vía del pacto y la negociación será la más utilizada.

\section{LOS ÚLTIMOS AÑOS DEL CONFLICTO}

Tras el enlace matrimonial los príncipes intentan seguir simultáneamente las dos vías de actuación que se abren frente a ellos. Ambas eran importantes dadas las circunstancias, pero difíciles de recorrer. La primera es la captación de la voluntad del reino, hacerse con partidarios en número suficiente como para imponer su candidatura frente a la de Juana. La segunda es la atracción de la voluntad del propio monarca, al que creen necesario volver a ganar para su causa.

${ }^{18}$ En la medida de sus posibilidades los príncipes realizan también mercedes a costa de sus posesiones y rentas para afianzar la fidelidad de sus partidarios, sirva como ejemplo el caso de Troilo Carrillo que el 17 de octubre de 1469 recibe la villa de Atienza (A.G.S., Patronato Real, Mercedes antiguas, leg. 59, fol. 1).

19 Zurita, J., Anales de la corona de Aragón. Zaragoza 1610, fols. 179-180. 
Por lo que se refiere a la primera cuestión, tienen que mantenerse atentos a dos poderes, la nobleza y los núcleos urbanos. En todo momento intentarán atender las aspiraciones de ambos con el fin de incrementar el número de sus defensores.

Respecto a la nobleza, Isabel cuenta con el apoyo de los Enríquez y los Manrique, pero esto es a todas luces insuficiente. Era preciso ampliar el abanico de alianzas y sobre todo atraerse a los Mendoza, familia que, al haber permanecido relativamente al margen del conflicto armado, y de los aspectos más escabrosos de la querella sucesoria, defendiendo en todo momento lo que consideraban los intereses de la corona, gozaban de amplia credibilidad y notable fuerza.

Pero atraer nuevos partidarios no era fácil, y las cosas se complican aún más a causa de los "celos" de Carrillo, cuya posición política difiere de la adoptada por Isabel, lo que le lleva a abandonar durante unos meses a su protegida, marchándose a Alcalá de Henares en enero de 1471. Con todo, van haciendo progresos, que se aceleran a partir de 1473. En esta fecha suscriben un acuerdo de confederación con el duque de Medinasidonia, hecho especialmente relevante ya que éste, además de comprometerse a intentar atraer al lado de los príncipes a la ciudad de Sevilla, acepta hacer lo mismo respecto a los Mendoza (todo ello a cambio de que Isabel aceptara su mayorazgo y se comprometiera a darle ayuda) ${ }^{20}$.

Al año siguiente, antes del fallecimiento del rey, los condes de Luna y de Alba apoyan ya a los príncipes, pero lo más sobresaliente es que éstos consiguen, por fin, aproximar a su causa a los Mendoza. Tras la lucha que se había producido entre el conde de Benavente y el marqués de Santillana por la posesión de la villa de Carrión, que ambos señores se disputan ${ }^{21}$ - en la que Fernando había apoyado la causa del marqués-, y con ocasión de la reunión que van a celebrar en Cuéllar los más altos representantes de la nobleza casteliana, Fernando se entrevista con los Mendoza. El de Santillana estaba agradecido por la actitud que el príncipe había adoptado en el conflicto de Carrión, de ahí que aceptara la entrevista, que se planeó de manera que pareciera fortuita, con el fin obvio de evitar las suspicacias que ese encuentro podía suscitar entre otros miembros de la clase nobiliaria. Tras salir de Monzón con dirección a Palencia los Mendoza se encuentran con la comitiva del prín-

20 Palencia, Alonso de, Crónica de Enrique $N$, escrita en latín por... y traducción castellana por A. Paz y Mélia, Madrid 1904-1907, Década II, libro VII, cap. V.

21 Véase Val Valdivieso, M. I. del, Ob. cit., págs. 331-332. 
cipe. Según narra Alonso de Palencia, el marqués se compromete a reconocer heredera a Isabel y a defender sus intereses en la reunión que iban a celebrar en Cuéllar ${ }^{22}$. Esta reunión fracasa, pero no la progresiva aproximación de los Mendoza a la causa de Isabel. Ésta, cuando el marqués, de paso hacia Guadalajara, se acerca la ciudad de Segovia, salió a saludarle al lugar de San Cristóbal, en un claro gesto de amistad.

A partir de estos acontecimientos, aunque siguen junto al rey, dado que es el legítimo monarca, los Mendoza comienzan a trabajar claramente en favor de la sucesión isabelina, e incluso parece que intentan convencer a don Enrique de la oportunidad política de aceptar a su hermana como heredera. Habrá que esperar hasta la muerte del rey para ver a los Mendoza junto a Isabel, pero ese paso estaba preparado ya desde hacía varios meses.

Así pues a lo largo de los últimos años del reinado de Enrique IV su hermana va consiguiendo nuevos adeptos entre los miembros de la más alta nobleza del reino, que confian en su capacidad política, y sobre todo en que su gobierno no lesionará sus intereses, más bien al contrario, que les será claramente beneficioso: tienen la convicción de que sin alejarles de las más destacadas esferas de poder, salvará el honor y buena fama de la corona, al tiempo que pacificará el reino, con lo que su posición como clase dominante se verá favorecida, y los frutos que de la misma esperan obtener, igualmente (obsérvese que esta opción política, representada ahora por la princesa, coincide en gran parte con la de aquel sector de la nobleza que hemos visto encabezado por los Mendoza). Junto a esto también debió influir la excesiva ambición y protagonismo de Juan Pacheco junto al rey, y el sometimiento de éste a quien considera su principal apoyo político ${ }^{23}$ : los excesos de Pacheco son públicos y no bien vistos por sus hermanos de clase, a los que en ocasiones perjudica. Precisamente es la conducta del marqués lo que decide en favor de Isabel a Andrés de Cabiera y al conde de Benavente, entre otros $^{24}$.

Si esto sucede entre la nobleza ¿qué papel adoptan los núcleos urbanos? el poder de éstos no ha hecho más que acrecentarse a lo largo de los últimos siglos, y aunque la crisis les ha creado serias dificultades,

22 Palencia, A. DE, ob. cit, libro IX, cap. V.

${ }^{23}$ En este sentido le presenta E. Amézaga, Enrique quarto, Madrid 1974, págs. 228234. El monarca le tiene en muy alto aprecio y siente hacia él gran estima, como puede verse en el doc. núm. 2 del apéndice.

${ }^{24}$ Véase apéndices 3 y 4. 
éstas no han mermado especialmente sus capacidades. Es cierto que la nobleza representa en algunos casos una seria amenaza, pero también es cierto que no faltan los que consiguen mantener su autonomía respecto al poder señorial, aunque para ello tengan que emplear la violencia.

Ya he señalado antes cómo son precisamente los núcleos urbanos los que presentan mayor resistencia a un importante aspecto de la política de Enrique IV, la concesión de mercedes de todo tipo, en especial los señoríos. Esto convierte teóricamente a las villas y ciudades en claros candidatos a defender la sucesión isabelina, desde el momento en que la propaganda de ésta se basa, en parte, en la denuncia de esa actitud real y en la defensa del patrimonio de la corona (aunque como ya he indicado antes, esa propaganda no coincide plenamente con la conducta seguida por la princesa). Pero si esto puede plantearse así en el plano puramente especulativo, es necesario contrastarlo con la realidad de los hechos, y éstos nos demuestran que la realidad es mucho más compleja.

En efecto, como enseguida veremos, el conflicto sucesorio es utilizado a nivel local para dirimir viejos conflictos y luchas por el poder, de manera que la hipótesis apuntada sólo se cumple cuando hay una resistencia activa y clara ante una donación que no se acepta. Este es, por ejemplo, el caso de Sepúlveda, núcleo que tiene una especial importancia estratégica dada su localización en el paso entre las dos Castillas, además de ser un próspero núcleo urbano. Cuando el rey se aproxima a ella a comienzos de 1472, sus vecinos, que temen ser entregados al marqués de Villena, a quien Enrique ha donado la villa pocos días antes, negocian con los príncipes, pasándose a su bando a cambio de que se comprometan a mantenerla en el realengo y a vivir allí alguna temporada. Para tomar posesión de la villa, los príncipes envían 170 jinetes al mando de Beltrán de Guevara y Pedro de Ávila, señor de Villafranca; posteriormente pasan al menos alguna breve temporada en ella: Fernando acude casi inmediatamente con el fin de asegurar su posesión, mientras que Isabel escribe desde aquí a Juan II de Aragón el 16 de noviembre de $1473^{25}$. Este mismo año otras villas se pasan también al bando de Isabel: ese es el caso de Moya, Aranda de Duero y Ágreda ${ }^{26}$.

Así pues, villas, ciudades y nobles van engrosando las filas de la princesa Isabel, que de estar en situación casi desesperada a comienzos

25 Val Valdivieso, M. I. DE, «La resistencia...", págs. 15-18.

26 Además de estas afiliaciones de carácter semipacífico, ya que casi siempre intervienen pequeños destacamentos, también se producen algunas por la vía de las armas, las más significativas son sin duda Tordesillas y Castronuño que son conquistadas por el ejército del rey de Sicilia. 
de 1471 , ha pasado a encontrarse muy bien respaldada en 1474. Esta circunstancia debió infiuir en el ánimo del rey y sus partidarios, pues don Enrique accede a verse con su hermana en Segovia.

Isabel hace su entrada en esa ciudad, una de las residencias favoritas de su hermano, en los últimos días de 1473, y permanecerá en ella durante todo el año siguiente. Es Andrés de Cabrera, marido de una antigua dama de la princesa, Beatriz de Bobadilla, quien facilita las cosas. Aunque Cabrera había ascendido en la corte enriqueña de la mano de Juan Pacheco y recientemente había firmado un pacto de colaboración con el mismo, se enfrenta con él cuando le es arrebatada, por causa del marqués, la tenencia del alcázar de Madrid ${ }^{27}$. Esta circunstancia, y la influencia de su mujer, debieron de decidirle en favor de la causa de la hermana del rey. Es así como el 15 de junio de 1473 se firma la capitulación según la cual Cabrera apoyará la causa de los príncipes, quienes juran, a su vez, respetar y velar por la vida de Enrique IV (vemos de nuevo una postura semejante a la de los Mendoza, es decir, el respeto absoluto al monarca legal y legítimamente establecido, pero una desconfianza hacia lo que pudiera acontecer respecto a su sucesión, y sobre todo en lo concerniente a la conveniencia de las alianzas que la llegada al trono de Juana podría suponer, en especial por la excesiva influencia que el monarca portugués podría ejercer sobre la corte casteIlana) ${ }^{28}$.

A cambio de esta declaración de respeto a la legitimidad del monarca y de acatamiento a su persona, Isabel va a lograr entrevistarse con su hermano y volver a su amistad, pero nada más; es decir, no consigue, a pesar de que lo intenta con entusiasmo e insistencia, que Enrique se retracte de lo hecho en Valdelozoya.

El rey acude a Segovia por Navidad, y la circunstancia es aprovechada por Cabrera y doña Beatriz para convencerle de la conveniencia de entrevistarse con su hermana. Enrique accede. No obstante, las circunstancias recomiendan actuar con precaución, de manera que la entrada de Isabel, acompañada por Carrillo, se realiza en semi-secreto, utilizando la oportunidad que les brindaba la ausencia del rey, que había salido a cazar a Valsaín. Al día siguiente, el 29 de diciembre, el monarca acude al alcázar a entrevistarse con su hermana. La cordialidad volvió a

27 Véase apéndice 3.

28 Sobre la actitud de Cabrera y el desarrollo de los acontecimientos puede verse la Crónica incompleta de los Reyes Católicos, editada por J. Puyol. Madrid 1934, págs. 109122. 
regir la relación entre ambos hermanos, pues el día 30 cenaron juntos, y en el transcurso del banquete Isabel bailó para Enrique, mientras éste la obsequió con sus canciones. La renovada amistad se hizo definitivamente pública cuando pasearon juntos por la ciudad el último día del año ${ }^{29}$.

Parece que don Enrique se mostraba dispuesto incluso a recibir a su cuñado, por lo que no se dejó pasar la ocasión. Fernando fue avisado, y cuando llegó a Segovia el propio monarca acudió a recibirle. A partir de este momento se sucedieron diversas entrevistas. Sin duda el rey, preocupado por los problemas que su sucesión estaba planteando, pretendía atraerse la voluntad de sus hermanos con la esperanza de pacificar el reino y evitar la guerra que a todas luces parecía estarse preparando para cuando llegara el momento de proceder a su relevo. Por su parte, los príncipes actúan también con la esperanza de evitar esa confrontación, pero a través, no de la simple reconciliación de las partes, sino con la condición irrenunciable de ser reconocidos por el rey como sus legítimos herederos.

Ni uno ni otro van a conseguir sus objetivos. La relación amistosa entre ambos es posible, pero ni Enrique está dispuesto a renunciar a que sea Juana quien le suceda, ni los príncipes a convertir esta amistad en una renuncia a sus aspiraciones, por lo tanto, el acuerdo es imposible. Por otra parte Pacheco, y los integrantes de la facción nobiliaria por él repiesentada, tampoco parecen estar dispuestos a que se llegue a un acuerdo, pues consideran que una posible victoria de los planes de los príncipes perjudicaría notablemente sus intereses; por esta causa no tardan en intervenir junto al rey con la intención de influir en su ánimo.

Todo parece estar en contra de la solución pactada en uno u otro sentido, y efectivamente el pacto no se logra. Fernando tiene que salir de Segovia por temor a una maniobra de los enemigos de su causa. Isabel se queda con la convicción de que contra ella sola no intentarán nada, pero la situación que tiene en la ciudad es difícil.

Ahora bien, a pesar del fracaso de este último intento de negociación entre ambas partes, la causa de los príncipes sale beneficiada del mismo, ya que han demostrado su voluntad de alcanzar una solución pacífica al problema, lo que a su vez posibilita que se presenten como los verdaderos defensores de los intereses de la corona y del reino. Ésto precisamente es lo que les va a permitir, casi un año después, ser coronados

29 ZURITA, J., op. cit., fol. 203v. 
reyes de Castilla en esa mismo ciudad, y contar con una notable ventaja de partida en la guerra civil con que inauguran su reinado.

\section{LA ACTITUD DEL REINO}

Diego de Valera indica ya que la noticia de la famosa deposión de Enrique IV en Ávila «a unos hizo temerosos y a otros más osados» ${ }^{30}$. Al calor de esos sentimientos los enfrentamientos se extienden por todo el reino, de tal forma que lo que hasta entonces habian sido muestras de descontento y protestas pacíficas, se convierten en luchas abiertas, que so color de apoyar a uno $u$ otro bando en conflicto, dirimen otro tipo de diferencias. Ciertamente la situación no es totalmente nueva, pues como dicen los procuradores de las Cortes de Toledo de 1462 en las "çibdades e villas e logares" del reino son relativamente frecuentes los escándalos y alborotos así como las «ligas e monipodios e confederaçiones» ${ }^{31}$, pero ahora no sólo esos «escándalos» se generalizan, sino que se acentúan $\mathrm{y}$ adquieren mayor trascendencia.

Esta circunstancia y el creciente descontento que despierta la política real (centrado en dos cuestiones fundamentales, la constante depreciación monetaria ${ }^{32}$ y la excesiva generosidad real a la hora de conceder a sus partidarios rentas y señoríos) hace que las quejas de los procuradores en Cortes se repitan e intensifiquen. Pero la actitud del reino no queda ahí. Conscientes de que semejantes quejas no conducen realmente a ninguna parte, son cada vez más frecuentes los intentos de resolver los problemas sin contar con la autoridad regia y aprovechando precisamente el conflicto sucesorio.

Si a través de ese conflicto los más conspicuos representantes de la nobleza del reino se enfrentan con motivo de su participación en las altas esferas de poder cortesano, dando lugar al mismo tiempo a una querella en torno a la concepción de la autoridad monárquica y la corona y del

30 VALERA, Diego DE, Memorial de diversas hazañas, publicado por C. Rosell, ob. cit., cap. XXIX, págs. 33-34.

${ }^{31}$ Cortes de los antiguos reinos de León y Castilla, T. III, Madrid, Real Academia de la Historia, 1866, págs. 709 y 728 (Cortes de Toledo de 1462, pet. 10 y 35).

32 VAL VALDIVIESO, M. I. DEL, «Un motivo de descontento popular. El problema monetario en Castilla durante el reinado de Enrique IV", Historia, Instituciones, Documentos, 8, 1982, págs. 1-20. 
papel que el rey debe jugar al frente de la administración del reino, en otros ámbitos la división que la existencia de los dos bandos nobiliarios impone va a dar cobijo a multitud de luchas locales por el poder, a través de los cuales diversas fuerzas se enfrentan por mejorar su posición, ampliar sus rentas, afianzarse o acceder al poder, etc.

Es decir, el conflicto sucesorio se vive muy de cerca y con gran intensidad en la mayor parte del territorio del reino, hasta el punto de que instituciones como la universidad se ven mezcladas, de forma más o menos indirecta, en el mismo, como lo demuestra el hecho de que en Salamanca, por ejemplo, un miembro del claustro del rector y consiliarios recomiende que el rector no acuda al llamamiento del conde de Alba fuera de la ciudad; la recomendación viene explicada, según su protagonista, para no dar la impresión de que tan seria institución toma partido o se somete a una autoridad señorial; y esto tiene lugar, cosa que explica la moción, en un momento en que Salamanca, resiste a dicho conde al que ha sido donada la ciudad por parte de Enrique IV ${ }^{33}$.

En definitiva, pues, de una u otra forma, todo el reino se ve afectado por el conflicto. Podemos ver varios ejemplos y diversas reacciones y formas de utilizarlo con diferentes fines.

En los territorios del Norte peninsular, donde la existencia de una pequeña nobleza local, que todavía no ha podido salir de la crisis, marca las relaciones sociales allí existentes, todo este conflicto sucesorio es aprovechado por esa pequeña nobleza para afianzarse en su posición, mediante la consecución de beneficios y ventajas otorgadas por los contendientes para mantenerlos a su favor, o bien a costa de sus inferiores o de sus iguales cuando la ocasión es favorable. Un ejemplo de ello nos lo ofrece Asturias.

En 1467 los asturianos presentan un capitulado en el que exponen su situación al infante don Alfonso, a cuyo lado se sitúan. En el mismo destaca el enorme poder que tiene el conde de Luna, así como el clima de división, violencia y extorsión que parece reinar en el Principado. Seguramente la pequeña nobleza local deseosa de mejorar su posición, y sin escrúpulos a la hora de hacerlo a costa de sus iguales, aprovecha la contienda general, y, con el pretexto de apoyar a uno $u$ otro bando en

${ }^{33}$ VAL VAldivieso, M. I. DEL, "Universidad y luchas urbanas en la Castilla bajomedieval", Mayurqa, 22, 1989, págs. 219-220. VALERA Diego, DE, ob. cit., cap. 53. pág. 55. Ya antes, en 1465 Salamanca tiene que nombrar un vicerrector dado que el rector ha sido desterrado por el corregidor por militar en un bando distinto al suyo (DEL VAL VALDIVIESO, idem, pág. 218). 
litigio, busca acrecentar sus rentas, bien mediante concesiones provenientes de la máxima jerarquía del grupo al que dicen defender, bien apropiándose violentamente de las propiedades y derechos de los integrantes de la parcialidad asturiana opuesta ${ }^{34}$.

Cuando los Reyes Católicos acceden al trono, Asturias presenta otro documento a la corte, y en el mismo observamos con claridad que la situación y el clima de enfrentamiento no ha cedido, más bien al contrario parece que la pequeña nobleza local ha aprovechado la situación de latente enfrentamiento existente desde la muerte del infante Alfonso para mantener su actitud. En efecto, en 1475 vemos como los procuradores se quejan de las múltiples violencias que protagonizan hidalgos y caballeros, que, amparados en sus fortalezas, castillos y casas fuertes, cometen toda clase de abusos, a través de los cuales podemos percibir la virulencia de la lucha de clases en un momento en el que la nobleza, ante la necesidad de rehacer y acrecentar su renta, no duda en recurrir a métodos tradicionales, haciéndose con prerrogativas de poder que no le corresponden ${ }^{35}$.

Si esto sucede en Asturias, en Andalucía el conflicto sucesorio va a ser aprovechado también para dirimir viejas contiendas nobiliarias. En un primer momento destaca el enfrentamiento de Pedro Girón con Miguel Lucas de Iranzo, por la posesión de Jaén, que el maestre de Calatrava intenta arrebatar a Miguel Lucas. Se trata de una plaza próspera y próxima a los dominios de la Orden, por lo que es vista por el maestre como una presa apetecible. Aprovechando desavenencias internas entre los caballeros y el condestable, al que se acusa, en palabras del cronista, de favorecer a «los populares» (piénsese que se trata de un recién llegado a las filas de la oligarquía urbana jienense), Pedro Girón intenta apoderarse de la ciudad ${ }^{36}$. No lo consigue, pero la posición del de Iranzo se hace difícil, dado que los bandos existentes en Jaén utilizarán, a partir

${ }^{34}$ Memorias de Enrique $N$, doc. 141, págs. 528-536.

${ }_{35}$ Documento publicado por URÍA Ríu, «Respuesta de los Reyes Católicos a las peticiones de la Junta General del Principado de Asturias en el año 1475", en Estudios sobre la Baja Edad Media asturiana, Oviedo 1979, págs. 142-152. Otras noticias sobre los bandos asturianos pueden consultarse en el artículo de Unía "Contribución al estudio de las luchas civiles y el estado social de Asturias en la segunda mitad del siglo XV", en Homenaje a $D$. José $M{ }^{\text {a }}$ Lacarra de Miguel, t. IV, Zaragoza 1977, págs. 285-305.

${ }_{36}$ VaLERA, Diego de, ob. cit., cap. XXXIII, pág. 37. Miguel Lucas de Iranzo fue nombrado por Enrique IV, el 3 de mayo de 1466, administrador general de las ciudades y villas del reino de Jaen, encargándole velar por los intereses de la corona en ese reino (Documento publicado en Colección diplomática del archivo histórico municipal de Jaén, siglos XIV y XV, Dirigida por J. Rodríguez Molina. Jaén 1980, doc. núm. 8, pág. 29. 
de ese momento, el conflicto sucesorio para, so color de defender a Enrique o a sus oponentes, ampliar su propio poder sobre la ciudad.

Un carácter más general tienen las luchas que enfrentan, a lo largo de varios años, al duque de Medinasidonia con los Ponce de León. Precisamente este largo enfrentamiento en torno al dominio sobre Andalucia explica, al menos en parte, el paso del primero, en 1473, a la causa de Isabel a cambio, como antes he indicado, de la promesa de ayudarle en la lucha contra el marqués. Por cierto que esta ayuda no llega a materializarse realmente a causa de las dificultades de todo tipo que los príncipes tienen; es cierto que Fernando pide a su padre el envío de cuatro galeras, pero éstas no llegarán nunca.

En otros ámbitos pueden encontrarse ejemplos igualmente expresiyos de cómo es utilizado el conflicto sucesorio por parte de las distintas fuerzas locales en litigio: Burgos, que procura obtener del mismo el máximo beneficio posible ${ }^{37}$. Valladolid, donde se habían impuesto los partidarios del Almirante y los príncipes en 1469 , pasa a la obediencia real en octubre de 1470 al imponerse la facción contraria, a la que favorecia más esta opción ${ }^{38}$.

El caso de Medina del Campo es similar. Esta villa fue donada a Isabel por parte de su hermano Alfonso, y posteriormente, en el pacto de Guisando, le es entregada por Enrique. La princesa toma posesión de Medina del Campo, pero su dominio efectivo sobre la misma se hace difícil: Enrique intenta recuperarla para su causa y esto anima a las facciones locales a utilizar el conflicto sucesorio para afianzarse sobre los contrarios. Así, cuando se imponen los partidarios del rey al frente del concejo, Isabel pierde la villa, aunque sólo pasajeramente, pues acabará ganándola de forma definitiva para su causa, y obtendrá de ella un importante apoyo en la guerra con que inicia su reinado ${ }^{39}$.

En otros casos la crisis sucesoria es aprovechada para defender la propia autonomía y/o deshacerse de algún molesto poder señorial.

Respecto a la primera cuestión destaca el caso de Vizcaya. En esta zona predomina, como en Asturias, una pequeña nobleza, muy celosa de sus derechos y privilegios, al tiempo que necesitaba de nuevos recursos

37 Guerrero Navarrete, $Y$., "Burgos y Enrique IV. La importancia del sector ciudadano en la crisis castellana de la segunda mitad del siglo XV», Hispania, 166, 1987, págs. 437484 .

38 Perez, J., Isabel y Fernando. Los Reyes Católicos. Madrid 1988, pág. 85.

${ }^{39}$ Valera, Diego DE, ob. cit., cap. LVIII, pág. 179. PalenCIA, ob. cit., Libro IV, cap. VIII, pág. 23. 
con que salir definitivamente de la crisis. Este último aspecto aviva las luchas banderizas - que afectan tanto al mundo rural como al urbanoa través de las cuales los linajes vizcaínos intentan defender y ampliar sus prerrogativas. En este, como en los casos anteriores, el conflicto interno provocado por la sucesión de Enrique IV influye y ampara, al tiempo que vela, las luchas que protagonizan los pequeños nobles de Vizcaya. En medio de esta situación la política enriqueña de relación con Francia empujará a los vizcaínos hacia los príncipes. La inclinación del monarca hacia el reino vecino es vista con enorme recelo en Vizcaya donde, debido a las actividades marítimas de sus habitantes y a su proximidad a la frontera, no se ve en absoluto ventajosa esa relación, hasta el extremo de desaconsejar, en 1470, el planeado matrimonio de doña Juana con el duque de Guyena.

Al año siguiente, 1471 , las diferencias entre el rey y los vizcaínos se agudizan a causa de la entrada del conde de Haro en ese territorio so pretexto de pacificar los conflictos internos. Este gesto es visto por los afectados como una afrenta a sus prerrogativas y una intromisión intolerable, ya que temen ser dominados por el conde, a lo que se resisten. Por esta causa el enfrentamiento con el rey se agudiza y comienza su aproximación a la causa de Isabel, incitada y apoyada por el conde de Treviño, enemigo del de Haro, y que en 1472 firma un ventajoso acuerdo con los príncipes. Ese mismo año Vizcaya reconoce a Isabel. La adhesión a su causa culmina en 1473, momento en el que la princesa se compromete a no apartar del dominio directo de la corona a este territorio ${ }^{40}$.

Por lo que se refiere a la segunda cuestión antes apuntada, la utilización del conflicto sucesorio para evitar clara y directamente el dominio señorial, recuérdese que ya me he referido a algunos casos como el de Sepúlveda alzada en armas contra el rey por esta causa. Otros ejemplos pueden traerse a colación, entre ellos el de Aranda de Duero, posesión de la reina doña Juana, entregada a la condesa de Tendilla, doña Elvira de Quiñones. Esta villa, que no ve forma de acabar con las luchas que enfrentan entre sí a los vecinos de las diferentes parcialidades, acaba entregándose a Isabel en 1473, cuando era posesión del conde de Miranda, Pedro de Estúñiga ${ }^{41}$.

En definitiva, pues, el reino vive muy directamente la crisis sucesoria, si bien no siempre se discuten realmente los derechos de una u otra

\footnotetext{
40 Val Valdivieso, M. I. DEL, Isabel de Católica..., págs. 289-290.

41 ldem, págs. 251 y 284. Consúltese también la nota 4.
} 
aspirante a la sucesión de Enrique, dado que, bajo el manto de ese enfrentamiento dinástico, en la mayor parte de los casos lo que se está dirimiendo es el acceso al poder o la defensa de diversas prerrogativas. La habilidad política de la hija de Juan II y de sus partidarios explica que muchas veces esas luchas locales se resuelvan en beneficio de su causa. $Y$ es esta política, unida a la actitud de respeto al monarca legítimo, lo que permitirá que en diciembre de 1474 , en Segovia, Isabel sea proclamada reina de Castilla. Pero esto no es suficiente para evitar la guerra civil, que ha venido fraguándose durante los años anteriores, y que estalla muy poco tiempo después. 


\section{APÉNDICE DOCUMENTAL}

DOCUMENTO N. 1

Sobre las fiestas celebradas en Toledo con motivo del nacimiento de doña Juana (Copia)

Biblioteca Nacional, Sección de Manuscritos, n. ${ }^{\circ} 13.236$

Cronica del nascimiento de la excelente que llamaron hija del rey $D$. Henrique el $4^{\circ}$ y por otro nombre la Beltraneja.

Domingo 6 de marzo del nascimiento del señor de mil (en blanco) nascio doña Juana, Infanta de Castilla, fija del mui Alto Rey don Henrrique nuestro señor, que Dios mantenga a su servicio y deje vivir por largos tiempos y buenos, amen. La qual nascio a hora de maytines, es fija ansimismo de la Reyna nuestra señora doña Juana, e que luego nascida sono en Toledo que fue desposada con el Infante don Alfonso, hijo del Rey Don Juan de ensclarecida memoria, que Diosa aya, padre del Rey nuestro señor. Este dia en Madrid donde nascio hicieron muchas alegrias de muchos juncos e toros, justas e otros placeres. $E$ dicen que nascio a la hora de entre las 10 y las 11 de la noche en el dicho dia Domingo. E luego en Toledo fue mandado pregonar por mandato del honrado Alonso Diaz de Montalvo, asistente en esta ciudad de Toledo, e Rexidores de ella que el Jueves siguiente en que fueron y se contaron 10 dias del dicho mes, que Viernes y Sabado folgasen todas las personas, e ficieron muchas danzas y corrieron toros y otras alegrias, lo qual asi se fizo e el dicho Jueves corrieron otros toros en la plaza de Zocodover de esta ciudad fasta visperas poco mas o menos, e facia grande agua aquel dia que no podian los peones e hombres a pie correr los dichos toros, los corrieron a caballo e a pie ciertos cavalleros, el qual tiempo era en quaresma fasta el dicho Jueves se comenzo a facer, e luego a 6 dias hubo procesión en la Iglesia maior de la dicha ciudad de Toledo, la qual procesion se hizo general en la dicha iglesia, y por ser el tiempo de todos no salio de la dicha iglesia e anduvieron por la claustra della todos vestidos con capas coloradas por las alegrias e vinieron ende todas las cruces de las iglesias e lanzas de los oficiales e Judios e Moros e los 
Moros vinieron fechos moros fasta 4 e danzando vestidos mui bien e danzando altamente e luego llegaron los dichos judios cerca de la puerta del perdon cavalgando dos Judios Rabines con sus atoras cantando en su Ley, otros Judios danzando de danzas de espadas e vestidos muy ricamente e aderezados, e andubieron todo el dia por casas de los cavalleros faciendo alegrias mui grandes. Esto duro fasta 6 dias e el sabado cesaron las danzas. E desque estaban con el rey nuestro señor en este tiempo al dicho nascimiento entonces los Embaxadores del Rey de francia en la dicha Madrid e otros muchos cavalleros e los fizo grandes fiestas e gasto grandes tesoros mostrando su gran poder.

DOCUMENTO N. 2

Carta de Enrique IV al marqués de Villena para que acuda en socorro de Toledo

$1473(?)$

A.H.N., Frias, cat. 8, n. ${ }^{\circ} 10$

El rey. Amado marqués, la cibdad de Toledo me escrivio como en ella andan algunas alteraciones, movidas por algunas personas de las de fuera, de manera que la cibdad esta para se quemar e destruir, e yo finque luego a lo remediar, salvo por dar despacho en las cosas de aca, en las quales sy plase a Nuestro Señor se dara muy presta conclusion e yo me podre partir luego, entre tanto porque segund la cibdad esta podra aver en ella grand daño, mucho vos ruego que vos llegueys alla, luego dexadas todas cosas, e esta gente mia con vos, que yo escrivo a los capitanes que fagan lo que vos les mandades e dedes en ello al mejor remedio que pudierdes por menjar que la cosa se allane, lo qual vos mucho graibcire.

Que os quiere como a si mismo, El Rey.

Por mandado del rey lohan de Mercado.

Para el Marqués de Villena. 
DOCUMENTO N. 3

Razonamiento hecho por Andrés de Cabrera al maestre de Santiago cuando éste intentó apoderarse del alcázar de Madrid que tenía el mayordomo

S.I., s.f. (Copia)

R.A.H., Colección Abella, t. X, fols. 390-392

Señor, si la virtud e nobleza nos obliga que olvidemos algunas vezes los deserviçios e gradescamos sienpre los serviçios que nos fizieren, quanto más devemos gradeszer e renumear al que sienpre sirvio e mira de serviçio. Bien sabedes señor quantas vezes e por quantas maneras Beltran de la Cueva a quien el rey hizo duque de Alburquerque e otros algunos de los que han estado çerca del rey procuraron muerte, daño e destruyçion de vuestra persona e estado, e sabedes bien que os avise de todas las cosas que os cunplian en todos los tienpos e logares que os fue nesçesario, e por $\mathrm{mi}$ aviso e consejo os proveystes de tal manera que fuestes libre de los daños que vos aparejavan. $E$ puse muchas vezes a peligro de muerte mi persona por salvar la vuestra, e non solamente tove manera con el rey que os toviese en su graçia e non creyese las malas ynformaçiones que contra vos continuamente le heran fechas, mas aun sienpre le di a entender que non podia ser bien servido sino perdonandos e trayendos a su serviçio aunque estabades en su deserviçio; e porque non me detenga repitiendo los serviçios que vos he fecho, pues en toda España son notorios, no se puede dezir con verdad que pasase dia ninguno fasta oy en todos los tienpos de las guerras e turbaçiones pasadas que agora sabiendolo vos o no lo sabiendo no vos fiziese serviçio señalado para que vuestra persona fuese libre de muerte e de prision e vuestro estado fuese guardado e conservado, donde ove muchas enemistades e perdi muchas e buenas amistades con grandes señores deste reyno porque ni sabia tener otro amigo ni reputar otro por enemigo salvo aquel que vos mandasedes, e queria señor que dixesedes si os deservi faziendo e si os dexe de servir no faziendo algo de lo que me mandasedes, ni menos podeys dezir que serviendos repeti mis serviçios os enoje demandando dellos gualardon y sienpre espere que os movierades a me remunerar con amor pues me movia e os servi con afecçion. Agora señor pareçeme que en remuneraçion de los trabajos que ove por conservar lo que teneys procurays con el rey que me quite lo que tengo digno por 
çierto e bien meresçiente remuneraçion de mis serviçios e trabajos. Decidme señor do esta aquel tienpo que la marquesa vuestra muger me llamaba padre de sus fijos e vos me llamavades fijo partiçionero de vuestros bienes con vuestros herederos, e do estan las promesas tan firmes e tan cunplidas que sin vos las pedir fezistes para me acreçentar e honrar. Mandays agora por ventura vuestro proposito porque mande yo el mio o aveys olvidado ya mis serviçios porque olvide yo de os servir o porque los perdi a daño con algunos deserviçios, no por çierto, mas paresçe bien que fueron devidamente fechos pues al fin ovieron este pago que me days. Cosa es por çierto señor esta que fazeys comigo no vista ni oyda en ninguna hedad de gentes, porque traer en olvido el benefiçio acaesçe muchas vezes tenerlo en memoria e disimularlo visto lo avemos, negar el benefiçio por no satisfazerlo muchos lo usan, pero confesar los serviçios e prometer por ellos grandes bienes e en logar dellos dar grandes males esto por çierto esçede todos limites de ingratitud. Yo señor no pido que me dedes de lo vuestro mas pido que no me quitedes lo mio, no pido cosa ynjusta ni difiçile de hazer mas pido cosa justa e muy razonable de otorgar. Todo honbre que alguna cosa se esfuerça a demandar deve considerar quien es el que la demanda e a quien la demanda e que es lo que pide e por que razon e en que tienpo lo pide e asy mismo si se puede o deve otorgar lo que pide. Yo señor soy quien vos bien conosçeys e vos soys un señor que yo pensaba conosçer, la cosa que pido es que non me fagays mal, e pidolo porque os he muy bien e lealmente servido y esto que pido vos señor no solamente podeys mas deveys lo faser en todo tienpo e en todos honbres espeçialmente en este tienpo e a mi a quien tantas vezes aveys fallado leal quantas vezes me aveys querido esprimetar, asi vos señor en pago de mis serviçios daño tan manifiesto determinays de me hazer, claramente veo que Dios justo gualardonador me muestra aver mucho errado quando con tan firviente ofiçio vos servia, e por çierto quando a tal servidor tal paga fazeys entiendo que fallays pocos servidores que tales ni semejantes serviçios os fagan. 
DOCUMENTO N ${ }^{\circ} 4$

Confederación de Andrés de Cabrera y el conde de Benavente sobre el servicio al rey y el problema sucesorio

1474, enero 11, Segovia

A.H.N., Osuna, leg. 417, n. $^{\circ} 20$

Las cosas asentadas e acordadas entre el muy magnifico señor conde de Benavente e Andres de Cabrera, mayordomo del rey nuestro señor e del su consejo, son las syguientes:

Primeramente es asentado e acordado quel dicho mayordomo de aqui adelante aya de ser e sea unanime e conforme con el dicho señor conde para conservar e guardar la pas e conformidad entre el dicho señor rey e los señores prinçipes sus hermanos, pospuesta toda cavala e simulaçion.

Ytem es acordado e asentado quel dicho mayordomo de aqui adelante aya de guardar e guarde la vida e persona e honra e casa e estado del dicho señor conde de Benavente bien e fiel e verdaderamente como la suya propia, e non consentira nin sera de fecho nin consejo en su muerte nin presyon nin detenimeinto nin desfasimiento de su estado, antes donde supiere o sintiere que lo tal se trata o quisiere faser lo arredrara e estorbara e resistira por todas las vias e maneras que pudiere e con todas sus fuerças e poder e gelo revelara e fara saber lo mas ayna que pudiere, e para todo ello se juntara con el dicho señor conde de Benavente con su persona, casa e gente e contra todas las personas del mundo de qualquier estado o condiçion o dignidad o preheminençia que sean, eclesyasticas e seglares; e donde quier que viere su provecho e honra lo allegara, e donde supiere o syntiere su daño lo arredrara syn eçebçion de persona, salvo eçebtando al duque de Alburquerque e la escritura que con el tiene fecha el dicho mayordomo; e que en todas cosas el dicho mayordomo aya de acatar e servir e acate e sirva de aqui adelante al dicho señor conde Benavente como a señor e padre.

Ytem es acordado e asentado que dicho mayordomo de aqui adelante non aya de faser nin faga amistad nin confederaçion alguna con alguna persona de qualquier dignidad condiçion e preheminençia que sea en contrario de lo suso dicho nin de cosa alguna nin parte dello, e que para validaçion e guarda de lo en esta escriptura contenido esta amistad e confederaçion aya de preçeder e 
preçeda a otras qualesquier que fasta aqui el dicho mayordomo tenga fechas, eçebto la que tiene fecha con el duque de Alburquerque.

Ytem es sentado e acordado quel dicho señor conde de Benavente de aqui adelante aya de ser e sea unanime e conforme con el dicho mayordomo Andres de Cabrera para la conservaçion de la persona e vida e real estado del dicho señor rey, e para conservar e guardar la pas e conformidad entre el dicho señor rey e los dichos señores prinçipes sus hermanos, pospuesta toda cabtela e simulaçion.

Ytem es acordado e asentado quel dicho señor conde de Benavente de aqui adelante aya de guardar e guarde la vida e persona e honra e casa e estado del dicho mayordomo bien e fiel e verdaderamente como la suya propia, e non consentira nin sera de dicho, fecho nin consejo en su muerte nin presyon nin detenimiento nin desfasimiento, antes donde supiere o sintiere que lo tal se trata o quiere faser lo arredrara e estorvara e resystira por todas las vias e maneras que pudiere, e para todo ello se juntara con el dicho mayordomo con su persona e casa e gente contra todas las personas del mundo de qualquier estado, condiçion o preheminençia que sean, eclesiasticas o seglares, e donde quier que viere su provecho e honra lo allegara, e donde supiere o syntiere su daño lo arredrara syn eçebtaçion de persona alguna; e que en todas las cosas el dicho señor conde aya de honrar e guardar e aprovechar al dicho mayordomo como a su propio e verdadero hijo.

Ytem es acordado e asentado quel dicho señor conde de aqui adelante non aya de faser nin faga amistad nin confederaçion alguna con ninguna persona de qualquier condiçion, dignidad o preheminençia que sea en contrario de lo suso dicho nin de cosa alguna nin parte deilo, e que para validaçion e guarda de lo en esta escriptura contenido esta amistad e confederaçion aya de preçeder otras qualesquier que fasta aqui el dicho señor conde tenga fechas.

Ytem es concordado e asentado que el uno syn el otro non faran trato nin conçierto alguno con el dicho señor rey e con los dichos señores prinçipes nin con el maestre de Santiago nin con otra persona alguna, e que si por alguna persona fuese movido trato alguno a qualquier dellos, que sy estoviesen en un logar, que en el mismo dia que se moviese lo revelara al otro, e sy estovieren absentes lo mas presto que pueda, por manera que qualquier cosa que se oviere de faser e asentar se faga de acuerdo e consenti- 
miento de amos e non el uno syn el otro, por manera que se remedien e faga lo que convenga a amos a dos; e asy mismo que sean conformes para que los dichos señores prinçipes ayan segura la subçesion destos reynos, e para que se faga el casaamiento del ynfante con la prinçesa doña Juana.

E yo el dotor Garsia Lopes de Madrid, del consejo del rey nuestro señor, seguro e prometo a vos los dichos señores conde de Benavente e mayordomo Andres Cabrera de faser e tener e guardar e conplir a vos los dicho señores e a cada uno de vos e con vos e con cada uno vos todas las cosas de suso contenidas, que vosotros avedes de faser e guardar el uno al otro e el otro al otro, segund que de suso son contenidas e declaradas. $E$ nos los dichos conde e mayordomo seguramos e prometemos de faser e tener e guardar e conplir a vos el dicho dotor e con vos todas las cosas de suso contenidas, que nos avemos de faser e guardar e conplir el uno al otro e el otro al otro.

Por çertificaçion de lo qual todo nos los dichos conde e mayordomo e dotor juramos a Dios e a Santa Maria e a esta señal de las crus $+e$ a las palabras de los santos evangelios do quier que mas largamente estan escriptos, e fasemos pleyto e omenaje una e dos e tres veses segun fuero e costunbre de España, yo el dicho conde en manos de Garsia Franco, onbre fijodalgo, que de mi lo resçibe, e yo el dicho mayordomo Andres de Cabrera en manos del dicho Garsia Franco que de mi lo resçibe, que bien e fiel e real e verdaderamente e syn arte e sin engaño e syn cabala alguna ternemos e guardaremos e conpliremos todo lo suso dicho e cada cosa e parte dello en esta escriptura contenido, e que non yremos nin vernemos contra ello nin contra parte dello agora nin en algun tienpo nin por alguna manera nin color nin rason que sea, so pena de perjuros e remetidos e caher en caso de menos valer, e en todas las otras penas e casos que cahen e yncurren aquellos que quebrantan juramento e pleyto e omenaje fecho e otorgado de su propia e libre voluntad; e que deste juramento e pleyto omenaje non pediremos relaxaçion nin absoluçion nin comutaçion a nuestro muy Santo Padre ni a dicho señor rey ni a otro jues eclesiastico o seglar ni a otra persona alguna que poder tenga para lo faser, e puesto que nos sea dado de su propio motu e çerta çiençia por los suso dichos o por qualquier dellos que non usaremos nin gosaremos dellos. En firmesa de lo qual otorgamos dos escripturas de un thenor, una para mi el dicho conde, e otra para mi el dicho mayordomo, las quales firmamos de nuestros nonbres e sellamos con los sellos de nuestras armas. 
Que fue fecha e otorgada esta dicha escriptura en la çibdad de Segovia a onse dias de enero, año del nasçimiento de nuestro señor lhesu Christo de mill e quatroçientos e setenta años.

El Conde.

Cabrera Mayordomo (sello).

Garsi Lopes dottor. 